\title{
Local perceptions and traditional methods for Carapa procera oil production in Mali
}

Received: 2019-10-22; revised: 2019-12-10; accepted: 2019-12-12

\author{
Urbain Dembélé1,", Aïssata A. Diallo', Anne Mette Lykke², Yénizié Koné ${ }^{3}$, Bino Témé4, Amadou Malé Kouyaté1 \\ 1. Institute of Rural Economy, Sikasso, Mali \\ 2. Aarhus University, Department of Bioscience, Silkeborg, Denmark \\ 3. Michigan State University Office, Bamako, Mali \\ 4. Institut of Rural Economy, Bamako, Mali \\ * Corresponding author. E-mail address: udembele@yahoo.fr
}

Summary: Carapa procera is a wild oil tree species traditionally exploited in Mali for seed oil. Carapa oil is highly sought because of therapeutic, cosmetic, insecticidal and repellent properties. The purpose of this work was to contribute to the understanding of local practices in carapa oil production and local perceptions related thereto. The method used was based on surveys in four production localities and tests of oil production according to the traditional processes practiced by the processors. Two methods of seed storage and oil extraction processes were identified. Women were the main actors in seed collection and oil processing. The average oil extraction efficiency from the seeds was $23.1 \%$ and varied among sites. The wet extraction process was the most efficient. In addition to socio-cultural considerations, difficulties related to technology (lack of adequate extraction equipment) and the decrease of carapa populations limit the full development of processing activities. It is necessary to undertake options to improve traditional oil production processes such as education and introduction of shea presses in order to reduce labour intensity, improve efficiency and ensure quality standards. It also requires action for the sustainable management and conservation of the carapa species.

Keywords: Carapa procera, efficiency, local processes, oil extraction, socio-cultural considerations, Sub-Saharan Africa.

\section{Perceptions locales et méthodes traditionnelles de PROduction de l'huile de CARAPA PROCE- RA AU MALI}

Résumé: Carapa procera est une espèce ligneuse oléagineuse naturelle traditionnellement exploitée au Mali pour l'huile des graines. L'huile de carapa est très recherchée pour ses propriétés thérapeutiques, cosmétiques, insecticides et répulsives. L'objectif de ce travail était de contribuer à la compréhension des pratiques locales en matière de production d'huile de carapa et des perceptions locales y afférentes. La méthode utilisée a été basée sur des enquêtes dans quatre localités de production et la réalisation des tests de production d'huile selon les procédés traditionnels pratiqués par les transformatrices. Deux méthodes de conservation des noix de carapa et d'extraction de l'huile ont été identifiées. Les femmes sont les principales actrices de la collecte des noix et de la production de l'huile. Le rendement moyen d'extraction de l'huile des graines a été de $23,1 \%$ et a varié entre les sites. Le procédé d'extraction de l'huile par voie humide a été le plus efficace. Outre les considérations socioculturelles, les difficultés liées à la technologie (manque d'équipements d'extraction adéquats) et la diminution des populations de carapa limitent le plein développement des activités de transformation. Il est nécessaire de développer des options pour améliorer les processus traditionnels de production de l'huile comme la formation et l'introduction de presses à karité afin de réduire l'intensité de travail, améliorer l'efficacité et garantir des normes de qualité. Cela implique également une action pour la gestion durable et la conservation de l'espèce carapa.

Mots clés: Carapa procera, efficience, procédés locaux, extraction de l'huile, considérations socioculturelles, Afrique subsaharienne. 


\section{INTRODUCTION}

In sub-Saharan Africa, wild tree species play an important role for livelihoods in most rural communities (HAHN \& al. 2018; Kalinganire \& al. 2007; VAn ANDEl 2006a). Among the socio-economically interesting products are oils from native trees used for food, body- and hair care and medicine, but their potential is far from fully exploited (Grace \& al. 2009). Enhanced oil production can therefore play an important role in income generation for local communities and contribute to food security and economic growth, particularly for women who traditionally make the oil products. Some studies have shown that there is potential for promoting new oil products from native trees in West Africa apart from shea butter and palm oil (KOUYATÉ \& al. 2015; OUÉDRAOGO \& al. 2013). These studies focused mainly on traditional knowledge of the use of these products, e.g. carapa oil.

Carapa procera is a promising oil species (MaIGA 2001; FAO 1996). In Africa, its range of distribution extends from Uganda to Senegal with Mali as the most northern distribution (WeBER \& al. 2010). Presently in Mali, carapa habitats are threatened because of degradation of native trees species due to increased deforestation caused by extensive agriculture and an increase in the number of agricultural farms (DembéLÉ \& al. 2016). In Mali flowering occurs from January to March (WEBER \& al. 2010), but can be earlier further south (Doligez \& JoLY 1997). Various parts of the tree (bark, leaves, gum, seeds, roots and wood) are used by local communities in southern Mali. The seeds are the most exploited plant part (DEMBÉLÉ \& al. 2015). The fruits are capsules with triangular brown seeds that mature from May to June. The fruits have a high oil content; about $55-60 \%$ (DJenontin \& al. 2012; SANOGo \& Sacandé 2007). This oil is widely used in traditional human and veterinary medicine body- and hair care and soap (DEMBÉLÉ \& al. 2015; Weber \& al. 2010; GUÈYE \& al. 2009) and also as repellent and insecticide (JiOfACK \& al. 2008; VAN ANDEL 2006b; SYLLA \& al. 2003). Marketing of carapa oil is often limited but has a potential to provide a significant source of income. However, the valorization and promotion of carapa oil requires an understanding of endogenous extraction processes.

This study aims to identify and describe traditional methods of seed storage, oil production and the socio-cultural perceptions related to carapa oil.

\section{Material and Methods}

\subsection{Study area}

The study was conducted in the Sudanian zone of Mali in the regions of Sikasso (villages of Ziékorodougou, Mourasso and Kountjila) and Koulikoro (village of Koumabougou) (Fig. 1). The choice of these localities was based on the availability of a natural habitat of carapa and traditions for use and processing by the local communities.

\subsection{Method}

The data were collected using semi-structured questionnaires with 30 women processors in each village and participant observations in January-February and June-July 2013. All participants were previously informed of the purpose of the study and the consent of each participant was obtained before starting data collection. The information collected was related to seed collection, seed storage, oil extraction and socio-cultural perceptions related to carapa in order to describe the exact steps and methods of production and equipment used.

\subsection{Data analysis}

Descriptive statistics were calculated. Oil extraction efficiency was determined by the formula: $\mathrm{R}=$ [Quantity of oil extracted / Quantity of processed kernels] x 100 (NoumI \& al. 2002, WoMeni \& al. 2002).

\section{Results}

\subsection{Socio-demographic characteristics of actors investi- gated}

The main actors in seed collection and processing of carapa oil were women. The average age of these operators was 47 years. Those in Mourasso were the oldest, 51 years in average, and those in Ziékorodougou the youngest, 42 years in average. Average age was 48 and 46 years in Koumabougou and Kountjila, respectively. The majority of these women $(90 \%)$ were married and 10\% widows. In Ziékorodougou all women were married, compared to $93 \%$ in Kountjila, 90\% in Mourasso and $77 \%$ in Koumabougou. Majority of women $(65 \%)$ were illiterate and never attended school, only $4 \%$ attended primary school, $6 \%$ koranic studies and $25 \%$ were literate in local languages. The average experience in exploitation of non-timber forest products (NTFPs) was 30 years and the average experience in exploitation of carapa was 20 years.

\subsection{Seed collection}

Seed collection took place at the beginning of the rainy season from May to June in gallery forests along river beds, where there is open access to harvesting of seeds. However, in some localities this period is extended to July for certain late fruiting individuals. Seed collection was regarded a demanding activity because of difficult access to carapa habitats, risks of slipping and falling and contact with snakes and scorpions that shelter in the bush. The daily collection time depended on the distance from the village and varied from 2 to more than 6 hours. The collection sites were closest from Koumabougou and Ziékorodougou (1-4 km), 4-6 $\mathrm{km}$ from Mourasso more than $6 \mathrm{~km}$ from Kountjila. The collection was mainly done by collecting fruit fallen on the ground.

\subsection{Processing of seeds and oil production}

Two processes of seeds and oil production were identified: the dry process (Fig. 2) and the wet process (Fig. 3). 


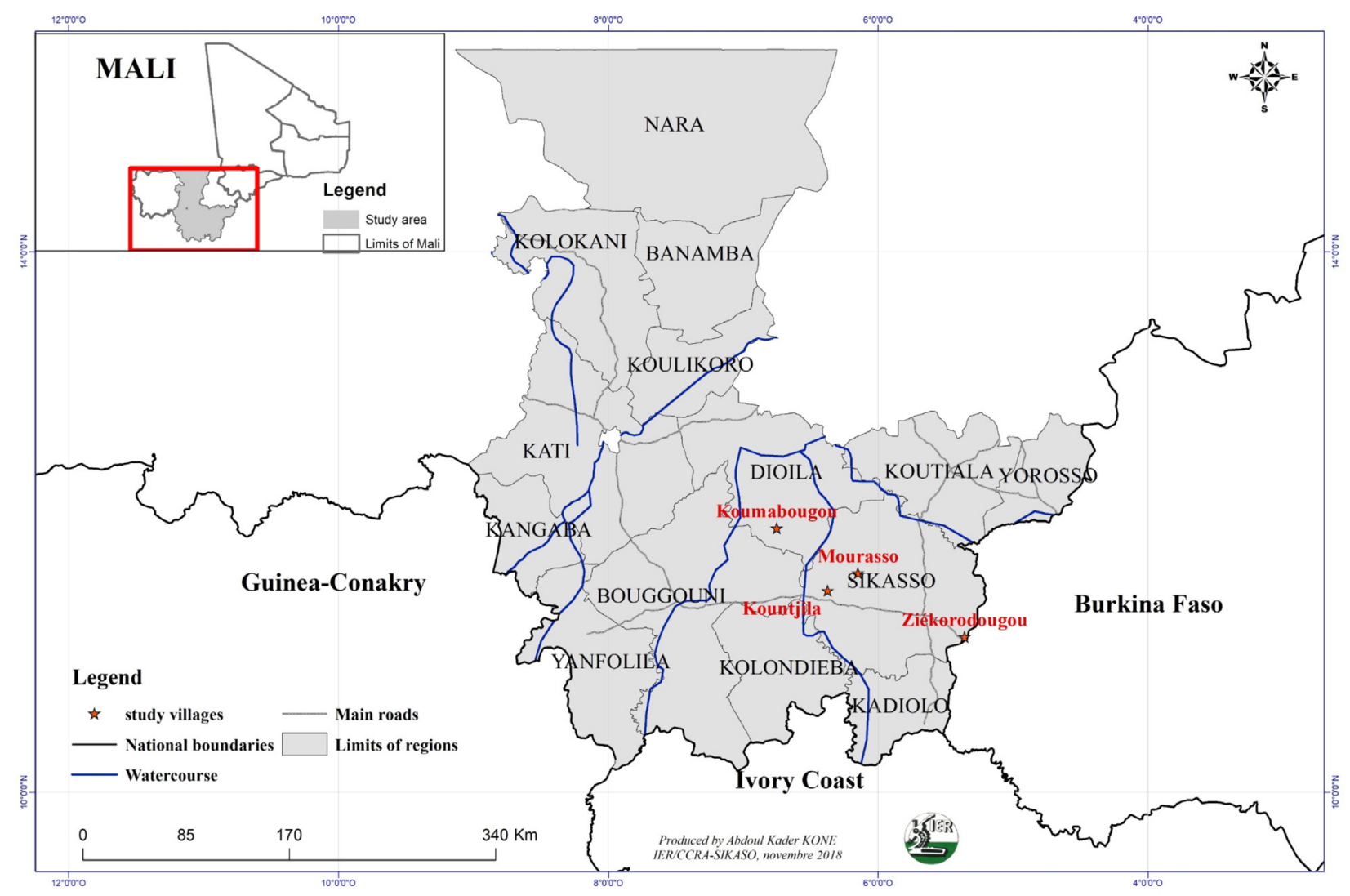

Fig. 1: Location of the study area/Localisation de la zone d'étude.

\subsubsection{The dry process (Dp)}

The dry process (Dp) was practiced in Ziékorodougou and Koumabougou. It was consisted in boiling the seeds in a pot with water (Dp1), the duration varied according to the quantity of seeds and the intensity of the fire. This process leads to a softening of kernels inside the seeds. By pressing the seed between the two fingers it was determined if they were tender. The seeds treated by boiling were stored in holes (Dp2) near the village. These boiled seeds were dusted with ashes and covered with soil. The storage duration was varied on when time was available for processing and ranged from 1 to 6 months. Commonly, the period of large-scale processing of oil occurred during the months of December to February after the crop harvest period. The seeds were dug up (Dp3) and shelling was done by hand using stones to crush the seeds, where after the kernels were extracted with a knife or similar suitable equipment (Dp4). The kernels obtained after shelling were grounded with a traditional millstone (Dp5). The resulting paste was prepared in the form of balls that were dried under sun (Dp6) for some duration varying according to the size of the balls (at least 1 day for small balls to several days for larger ones). After drying, the balls were cooked in a pot and mixed to a paste with addition of water or boiled plant extracts (Dp7). The commonly used plant extracts were mainly based on leaves from $\mathrm{Pa}$ vetta crassipes (Rubiaceae), Piliostigma reticulatum (Fabaceae-Ceasalpinioideae) and Argemone mexicana (Papaveraceae) called "kumu-ba", "gnama-bulu" and "ngoni-dièni" respectively in the local language, Bamanakan. According to processors, the use of these additives was intended to stabilize the oil extraction. The oil was decanted from the paste (Dp8), cooled and stored in various materials.

\subsubsection{The wet process (Wp)}

The wet process $(\mathrm{Wp})$ was practiced in Kountjila and Mourasso. It was consisted in drying the collected seeds under sun and roasting them at a constant temperature in a traditional furnace (Wp1) commonly made in terra cotta and fuelled by a wood. Roasted seeds were commonly stored in jute bags or canaries (Wp2) and kept in specific shelters in the houses. The storage duration was ranged from 1 to 6 months depending on when time was available for processing. Similarly, to the dry method, the main processing period was during the months of December to February after crop harvest. For processing, the seeds were destocked (Wp3) (removed from storage) and the shell was broken manually using stones or other suitable equipment to extract the kernels (Wp4). The kernels were crushed and grounded with a traditional millstone or a conventional mill (Wp5). The paste obtained after crushing was mixed and churned by hands by periodically adding cold water until a whitish cream was obtained (Wp6). This white cream was heated in a pot to obtain the oil (Wp7), which was decanted to remove impurities (Wp8) and subsequently packaged in various materials. The churning process was commonly carried out very early in the morning during the cold season (from December to January) before the sunrise and could often be completed in 


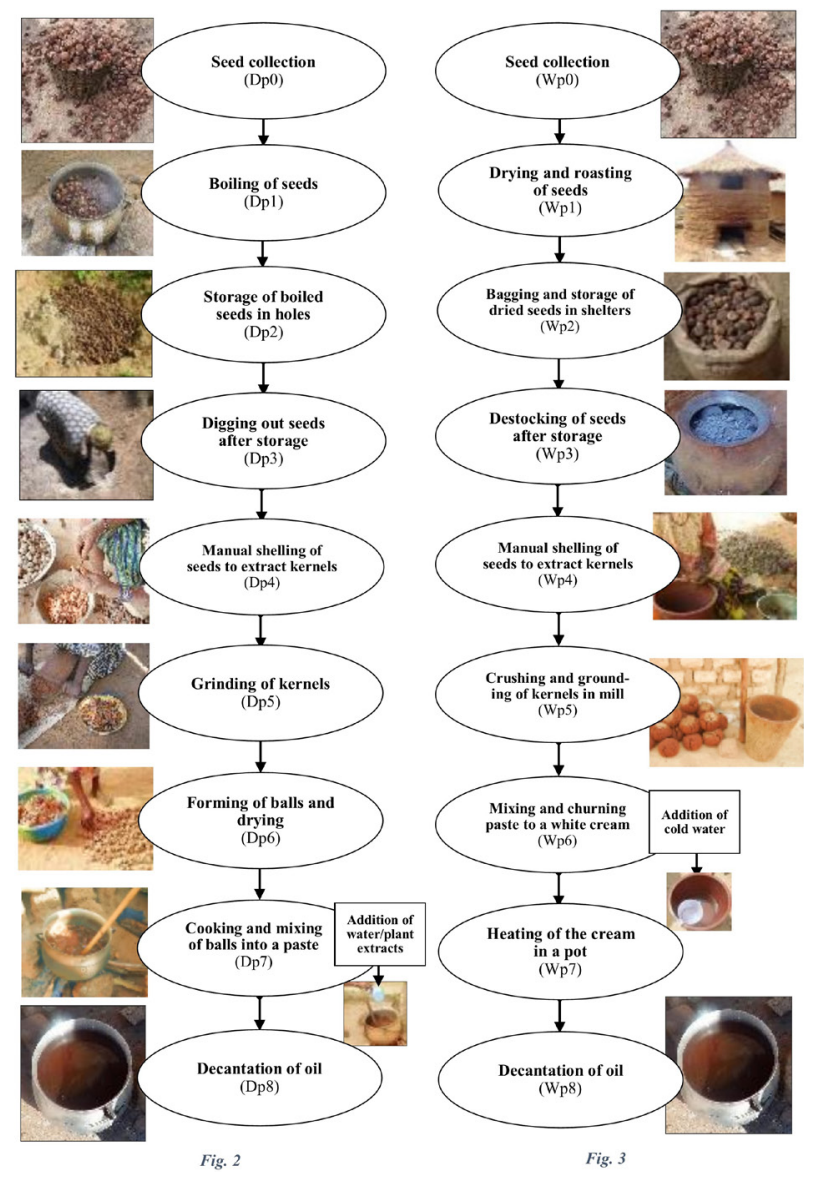

Fig. 2: Diagram of carapa oil extraction by dry process /Diagramme d'extraction de l'huile de carapa par voie sèche.

Fig. 3: Diagram of carapa oil extraction by wet process / Diagramme d'extraction de l'huile de carapa par voie humide

2 to 3 days. The women stated that the longer the duration of the churning, the higher the extraction efficiency.

Oil samples collected during the study showed a variation in coloration (Figure 4). Oil produced by the dry process had a darker coloration than that obtained by the wet process.

\subsection{Oil extraction efficiency}

The oil extraction efficiency ranged from an average of $21.16 \%$ in Koumabougou to $25.27 \%$ in Kountjila (Table 1). The wet extraction process average efficiency $(25.02 \%)$ was higher than the dry process $(21.80 \%)$.

\subsection{Socio-cultural perceptions and constraints}

Carapa oil production was considered of socio-cultural importance and several magico-mystical specificities were related to the production. The common perception was not to collect seeds and extract oil during menstrual periods for women in child-bearing age. This explains the common perception that carapa exploitation is more devolved for menopausal women. For this reason, it was also not permitted for a menstruating woman to step over the carapa seeds to avoid the risk that the seeds will not produce oil. These considerations relate to an assumption that carapa seeds will not tolerate blood. It was also reported that the processor must be free from criticism and reproaches and not be angry when

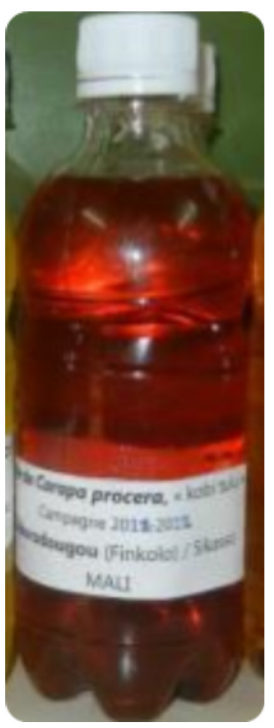

Fig. $4 a$

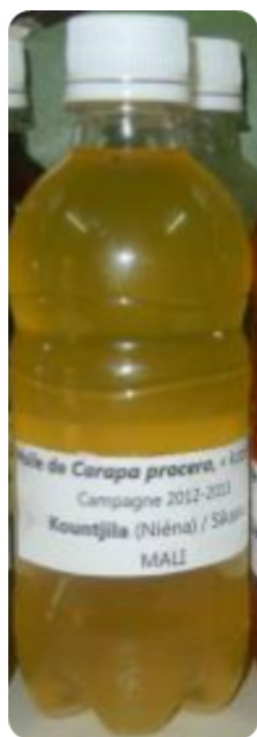

Fig. $4 b$
Fig. 4: Samples of oil produced by dry process (a) and by wet process (b) / Echantillons d'huiles produites par voie sèche (a) et par voie humide (b).

starting the oil production process. According to them, this perception refers to the state of purity that must be achieved in order to produce the oil successfully. This state of purity and cleanliness was also desired during the storage of seeds. For this reason, women say they keep seeds away from unsanitary conditions such as urine. It is also prohibited to steal or cheat during seed collection, otherwise the oil during processing will not be good.

However, despite compliance with most of these rules, it happens that during the processing stage, no oil is obtained. According to the producers, this situation is perceived as a sign of bad news that can affect the producer or her family and/or friends (i.e. diseases, accidents, deaths, tragic events or bad luck).

The main constraints mentioned by the processors are the drudgery associated with the processing due to the lack of adequate equipment and the decrease in the carapa trees, which reduces the potential for production.

\section{Discussion}

Women are the main operators of carapa seeds collection and oil processing. It seems obvious in Africa that women are the main actors in the exploitation and processing of non-timber forest products (BuP \& al. 2014; Pоuliot 2012; NATTA \& al. 2010; SAUSSEY \& al. 2008; MBÉtid-BesSANE 2005). The producers were mainly older women. As WeBER $\&$ al. (2010) reported, the collection of carapa seeds in Mali occurs in May-June. There are constrains for women in this period as they are highly involved in agricultural activities and therefore forced to stock the collected seeds for a more suitable time for processing. Women collect seeds fallen in the ground, which is the commonly recommended method, because it ensures that the fruits have reached maturity and 
Table 1: Oil extraction efficiency according to the extraction processes / Rendement d'extraction de l'huile en fonction des procédés.

\begin{tabular}{|l|l|c|c|c|c|}
\hline Method & \multicolumn{1}{|c|}{ Study site } & Number of samples & \multicolumn{3}{|c|}{ Extraction efficiency (\%) } \\
\cline { 4 - 6 } & & & Mean & Minimum & Maximum \\
\hline \multirow{5}{*}{ Dry process } & Koumabougou & 3 & $21.16 \pm 1.09$ & 19.85 & 23.33 \\
\cline { 2 - 6 } & Ziékorodougou & 3 & $22.43 \pm 1.55$ & 19.64 & 25.00 \\
\cline { 2 - 6 } & Total & $\mathbf{6}$ & $\mathbf{2 1 . 8 0} \pm \mathbf{0 . 8 9}$ & $\mathbf{1 9 . 6 4}$ & $\mathbf{2 5 . 0 0}$ \\
\hline \multirow{3}{*}{ Wet process } & Kountjila & 2 & $25.27 \pm 0.82$ & 24.44 & 26.09 \\
\cline { 2 - 6 } & Mourasso & 2 & $24.77 \pm 0.96$ & 23.81 & 25.74 \\
\cline { 2 - 6 } & Total & $\mathbf{4}$ & $\mathbf{2 5 . 0 2} \pm \mathbf{0 . 5 4}$ & $\mathbf{2 3 . 8 1}$ & $\mathbf{2 6 . 0 9}$ \\
\hline
\end{tabular}

are suitable for production of high quality butter (АноUANSOU \& al. 2012; NATTA \& al. 2010; Noumi \& al. 2006; Womeni \& al. 2005; Mbétid-Bessane 2005; KAPSEU \& al. 2002).

For storage, two methods of pre-treatment of carapa seeds (boiling and drying) were practiced. These methods are comparable to those of shea nuts described by AHouAnsou $\&$ al. (2012). According to WEBER \& al. (2010), the storage of boiled seeds in holes in the ground could facilitate the breakdown of the tegument and make the seed easier to peel. In comparison, the drying before storage of carapa seeds used by some women is not recommended by WoMENI \& al. (2006) in the case of shea nuts, because it can cause biochemical modifications that affect the quality of the butter.

The two processes of carapa oil extraction are similar to those described for the production of shea butter by DANDJOUMA \& al. (2009). These traditional processes are labourintensive, particularly for shelling. In general, traditional processing methods are slow and labour-intensive (GRACE \& al. 2009).

The drying stage of balls made from grinded carapa kernels during dry process is varies in duration, ranging from 1 day to 4 weeks (WeBER \& al. 2010). However, the practice of some women of drying balls on the ground exposes the balls to a range of impurities, which is not good practice according to Ahouansou \& al. (2010). As found in this study, the use of plant ingredients to stabilize the production was also reported by WEBER \& al. (2010).

In the case of wet extraction, water temperature and frequency of water addition influenced the duration and water requirements in the churning process (SoN \& al. 2012). A correlation between churning duration and extraction efficiency was also found (BADOUSSI \& al. 2015). The extraction efficiency of carapa oil in this study was comparable to that obtained by KAPSEU \& al. (2002) in the extraction of safou oil (Dacryodes edulis) in the range of $23-28 \%$ by manual press.

The visual appreciation of the quality of oil showed a difference in the colouring. Traditional oil production is generally not uniform (KAPSEU 2009). The variation in physicochemical characteristics was found to be related to the duration and temperature of the roasting and frying process (BADoussi \& al. 2015). These statements indicate a need for quality standards in the production of carapa oil and it has been argued that production should ensure safety and quality standards whether the product is intended for food or other uses, for local markets or for export (GRACE \& al. 2009). A compliance of oil products with quality and safety standards can provide protection not only to the consumer but is crucial for export markets.

\section{CONCLUSION}

The study has highlighted two traditional processing methods for extracting carapa oil, the dry and the wet processes. The wet process was the most efficient with an average efficiency of $25 \%$. However, it is necessary to perform a more in-depth comparative analysis to determine the influence of treatment and seed storage techniques on the physico-chemical characteristics and quality of the oil produced and also to estimate the financial profitability of the two processes of carapa oil.

The promotion of carapa oil production for the benefit of local communities could be improved by: improving processing by introducing appropriate technologies such as shea presses to increase extraction efficiency and quality of oil, educating women in the best practices, promoting carapa domestication strategies to increase seed availability and continuous supplies and ensure sustainable use.

\section{Acknowledgements}

The work was funded Qualitree (Danida 10-002AU) and Treefood (Agropolis, Cariplo and Carasso Foundations' Thought for Food Initiative). Authors sincerely thank all participants in the study villages for their frank cooperation and knowledge sharing.

\section{Conflict of interest statement}

Authors declare that they have no conflict of interest.

\section{REFERENCES}

Ahouansou R, Dohou Videgnon B, Fandohan P, Soglo A, Koumassa L, Klotó́ A, Agnila B, Adéoti R, CouliBaly O, Koudandé OD \& Mensah GA (2010): Bonnes pratiques de production, de transformation et de commercialisation des amandes et du beurre de karité. Fiche technique.

Ahouansou RH, Houssou P, Dan CBS, Agbobatinkpo P, AdéKambi S, Gnonlonfin GJB, Fanou L, Koumassa L, Hell K, Adéoti R, Coulibaly O, Vidégnon BD, AhousSi AL, Fandohan P, Koudandé OD, Mensah GA, Dohou VidÉGNON B, Ahoussi AL, FANDOHAN P, Koudandé OD \& Mensah GA (2012): Savoir-faire endogènes pour la valorisation du fruit de karité au Bénin en Afrique de l'Ouest. Bull la Rech Agron du Bénin 71:38-45.

Badoussi E, Azokpota P, Madodé Ye, Amoussou BF, Tсhово FP, Kayodé APP, Dossou A, Soumanou MM \& 
Hounhouigan DJ (2015): Effet des opérations unitaires d'extraction sur le rendement et la qualité du beurre de Pentadesma butyracea produit en milieu traditionnel au Bénin. J Appl Biosci 86:7976-7989.

Bup DN, Mohagir AM, Kapseu C \& Mouloungui Z (2014): Production zones and systems, markets, benefits and constraints of shea (Vitellaria paradoxa Gaertn) butter processing. Oilseeds fats Crop Lipids 21:1-5. doi: 10.1051/ ocl/2013045.

Dandjouma AKA, Adjia HZ, Kameni A \& TchiÉGANG C (2009): Procédés traditionnels de production et circuit de commercialisation du beurre de karité au Nord-Cameroun. Tropicultura 27:3-7.

DembéLÉ U, Koné Y, TÉmÉ B, LykKe AM \& Kouyaté AM (2016): Préférences ethnobotaniques des espèces ligneuses locales exploitées pour la production d'huile végétale dans le cercle de Sikasso, Mali. Afrika Focus 29:49-65.

Dembélé U, Lykke AM, Koné Y, Témé B \& Kouyaté AM (2015): Use-value and importance of socio-cultural knowledge on Carapa procera trees in the Sudanian zone in Mali. Ethnobiol Ethnomedicine 11:1-10. doi: 10.1186/1746-426911-14.

Djenontin TS, Wotto VD, Avlessi F, Lozano P, SoHounhloué DKC \& Pioch D (2012): Composition of $\mathrm{Az}$ adirachta indica and Carapa procera (Meliaceae) seed oils and cakes obtained after oil extraction. Ind Crops Prod 38:39-45. doi: 10.1016/j.indcrop.2012.01.005.

Doligez A \& Joly HI (1997): Mating system of Carapa procera (Meliaceae) in the French Guiana tropical forest. Am J Bot 84:461-470.

FAO (1996): Arbres du terroir pour l'alimentation. Projet GCP/RAF/303/ITA, Forêt et sécurité alimentaire en Afrique Sahélienne, Sikasso.

Grace OM, Borus DJ \& Bosch CH (2009): Oléagineux de l'Afrique tropicale. Conclusions et recommandations basées sur PROTA 14: "Oléagineux". [Traduction de: Vegetable oils of Tropical Africa. Conclusions and recommendations based on PROTA 14: 'Vegetable oils'. 2008]. Fondation PROTA, Wageningen, Pays-Bas, pp 1-86.

Guèye M, Kenfack D \& Forget P-M (2009): Importance socio-culturelle, potentialités économiques et thérapeutiques du Carapa (Meliaceae) au Sénégal. In: X. van der Burgt, J. van der Maesen \& J.-M. Onana (eds), Systematics and conservation of African plants. Royal Botanic Gardens, Kew, pp 357-365.

Hahn K, Schmidt M \& Thiombiano A (2018): The use of wild plants for food: a national scale analysis for Burkina Faso (West Africa). Flora Veg Sudano-Sambesica 21:25-33. doi: $10.21248 /$ fvss.21.57.

Jiofack T, Fokunang C, Kemeuze V, Fongnzossie E, TsaBANG N, Nkuinkeu R \& NkongmenEck BA (2008): Ethnobotany and phytopharmacopoea of the South-West ethnoecological region of Cameroon. J Med Plants Res 2:197-206.

Kalinganire A, Weber JC, Uwamariya A \& Koné B (2007): Improving rural livelohoods through domestication of indigenous fruit trees in the parklands of the Sahel. Fruit trees 10:186-203.

KAPSEU C (2009): Production, analyse et applications des huiles végétales en Afrique. Oilseeds fats Crop Lipids 16:215-229.

Kapseu C, Avouampo E \& Djeumako B (2002): Oil extraction from Dacryodes edulis (G.Don) H.J.
Lam fruit. For Trees Livelihoods 12:97-104. doi: 10.1080/14728028.2002.9752413.

Kouyaté AM, Dembélé U \& LykKe AM (2015): Les espèces ligneuses locales à huile : une ressource utile pour les communautés locales au Sud du Mali. Int J Biol Chem Sci 9:2754-2763.

MaIGA AS (2001): Situation des ressources génétiques forestières du Mali. In: Atelier sous-régional FAO/IPGRI/CIRAF sur la conservation, la gestion, l'utilisation durable et la mise en valeur des ressources génétiques forestières de la zone sahélienne. Ouagadougou, 22-24 sept. 1998.

Mbétid-Bessane E (2005): Caractérisation du marché des huiles de karité en Centrafrique. Tropicultura 23:141-145.

Natta A, Sogbégnon R \& Tсново F (2010): Connaissances endogènes et importance du Pentadesma butyracea (Clusiaceae) pour les populations autochtones au Nord Ouest Bénin. Fruit, Veg Cereal Sci Biotechnol 4:18-25.

Noumi GB, Dandjouma AKA, Kapseu C \& Parmentier M (2006): Le savoir-faire local dans la valorisation alimentaire des fruits du safoutier (Dacryodes edulis (G. Don) H. J. Lam) au Cameroun. Tropicultura 24:58-62.

Noumi GB, Ngameni E, Kapseu C \& Parmentier M (2002): Variation de la composition en acides gras et en triglycérides de l'huile des fruits de l'aiélé en fonction des conditions d'extraction et de la couleur du fruit. La Riv Ital Delle Sostanze Grasse 79:315-318.

OUÉdRAOGO A, LyKKe AM, LANKOANDÉ B \& KorbÉOGO G (2013): Potentials for promoting oil products identified from traditional knowledge of native trees in Burkina Faso. Ethnobot Res Appl 11:71-83.

Pouliot M (2012): Contribution of "Women's gold" to West African livelihoods: the case of shea (Vitellaria paradoxa) in Burkina Faso. Econ Bot 66:237-248.

Sanogo S \& SaCAndÉ M (2007): Carapa procera DC. Seed Leaflet. Forest \& Landscape Denmark, Hørsholm.

Saussey M, Moity-Maizi P \& Muchnik J (2008): Nouvelles formes de reconnaissance des femmes burkinabè dans la production de beurre de karité. Cah Agric 17:582-586.

Son G, Ye SG \& Kabore A (2012): Besoins et pratiques du dosage de l'eau du procédé d'extraction du beurre de karité par barattage. J la Rech Sci l'Université Lomé 14:45-52.

Sylla M, Konan L, Doannio JMC \& Traore S (2003): Evaluation de l'éfficacité de lotions et de crèmes à base d'huiles de coco (Cocos nucifera), de palmiste (Eleais guineensis) et de gobi (Carapa procera) dans la protection individuelle contre les piqûres de Simulium damnosum s.l. en Côte d'Ivoire. Bull la Société Pathol Exot 96:104-109.

VAN ANDEL T (2006a): Les produits forestiers autres que le bois d'œuvre. La valeur des plantes sauvages. In: Agrodok 39. Fondation Agromisa et CTA, Wageningen, 80 pages.

VAN ANDEL T (2006b): Non-timber forest products. The value of wild plants. In: Agrodok 39. Agromisa Foundation and CTA, Wageningen, 69 pages.

Weber N, Birnbaum P, Forget P, Gueye M \& Kenfack D (2010): L'huile de carapa (Carapa spp., Meliaceae) en Afrique de l'Ouest: utilisations et implications dans la conservation des peuplements naturels. Fruits 65:343-354. doi: $10.1051 /$ fruits/2010029.

Womeni HM, Kamga R, Tchiegang C \& Kapseu C (2002): Extraction du beurre de karité: influence du séchage des 
amandes et de la technique d'extraction. La Riv Ital Delle Sostanze Grasse 79:33-37.

Womeni HM, Ndjouenkeu R, Kapseu C, Mbiapo FT, ParMENTIER M \& FANNI J (2006): Effet de la cuisson et du séchage des noix de karité (Butyrospermum parkii (G . Don) Kotschy) sur la qualité du beurre. Tropicultura 24:175-182.
Womeni HM, TChagna DT, NDJOUEnkeu R, Kapseu C, Mbiapo FT, Linder M, Fanni JJ \& Parmentier M (2005): Influence des traitements traditionnels des graines et amandes de karité sur la qualité du beurre. Notes techniques: Food Africa, Yaoundé. 